https://helda.helsinki.fi

\title{
The roles of competition and climate in tree growth variation in northern boreal old-growth forests
}

\section{Aakala, Tuomas}

2018-11

Aakala , T , Berninger , F \& Starr , M 2018 , ' The roles of competition and climate in tree growth variation in northern boreal old-growth forests ' , Journal of Vegetation Science, vol. 29 , no. 6 , pp. 1040-1051 . https://doi.org/10.1111/jvs.12687

http://hdl.handle.net/10138/327084

https://doi.org/10.1111/jvs.12687

unspecified

acceptedVersion

Downloaded from Helda, University of Helsinki institutional repository.

This is an electronic reprint of the original article.

This reprint may differ from the original in pagination and typographic detail.

Please cite the original version. 
1 The roles of competition and climate in tree growth variation in northern boreal

2 old-growth forests

3

4 Tuomas Aakala ${ }^{1}$, Frank Berninger ${ }^{2}$, Mike Starr

5 Department of Forest Sciences, University of Helsinki, Finland

6

$7 \quad{ }^{1}$ https://orcid.org/0000-0003-0160-6410

$8 \quad 2$ https://orcid.org/0000-0001-7718-1661

9

10 Correspondence

11 Tuomas Aakala

12 Department of Forest Sciences,

13 P.O. Box 27, FI-00014 University of Helsinki, Finland

14 E-mail: tuomas.aakala@helsinki.fi

15

16

17 Funding information:

18 The project was funded by the Academy of Finland (project no. 252629) and the Emil Aaltonen

19 foundation, and the manuscript was finalized with support from the Kone Foundation. 


\section{Abstract}

Questions How have tree growth and growth trends varied in structurally complex old-growth forests? What determines this variation, and how this differs among species?

Location Naturally developed boreal old-growth forests at high latitudes in northern Finland Methods We sampled trees over $10 \mathrm{~cm}$ diameter on 48 randomly located 0.1 ha plots in three landscapes, and compiled a dataset of 1565 trees including all three main species, and a full range of sizes and competitive states in northern boreal old-growth forests. We extracted tree ring samples from every tree, and used ring widths to reconstruct tree sizes and their neighborhood for the past 50 years for Pinus sylvestris and Picea abies, and 30 years for Betula pubescens. We used mixedeffects models to study variation in tree growth. In the models, we used annually varying environmental variables, forest and tree structural variables and site variables as predictors. We also measured soil hydraulic properties for a water balance model to specifically include soil moisture deficits as predictors.

Results Tree growth rates had increased during the analysis period for all three species, with the highest increases for P. sylvestris and B. pubescens. All three species grew well during warm summers, but $P$. sylvestris and $P$. abies growth was also negatively influenced by soil moisture deficits. Competition in these sparse forests had a small influence on growth. However, its influence increased over time.

Conclusions The trees showed positive growth trends, but the increasing competition means that such strong positive trends are unlikely to continue over the long-term. For year-to-year variability, negative influence of droughts implied that increasing temperatures are not only beneficial to tree growth even in these high latitude forests. Overall, the findings demonstrate the site- and speciesdependent complexity in tree responses to environmental and structural changes we may expect in the future. 
Keywords: Drought; Tree ring; Picea abies; Pinus sylvestris; Betula pubescens; Mixed-effects model; Forest dynamics; Natural forest

\section{Introduction}

Boreal forests cover large areas of northern Europe and, importantly, high latitudes encompass a sizeable share of Europe's remaining intact forest landscapes (Potapov et al. 2017). Predicting their future requires understanding the factors that influence the growth of different tree species. Earlier studies from different biomes have demonstrated immense variation in tree growth at multiple time scales, ranging from year-to-year variation to long term, trend-like changes (Bowman et al. 2013). Such variation at different time scales can be driven by a multitude of factors, including tree size, tree-tree interactions, and climatic variability (Coomes \& Allen 2007; Gómez-Aparicio et al. 2011). However, in many respects the high latitude forests have characteristic features that set them apart from lower latitude forests, including low tree species diversity, a short growing season, low sun angles, and a sparse canopy cover. Hence, factors influencing tree growth are also likely to vary from those documented at lower latitudes (Fraver et al. 2014).

In general, tree growth in high latitude boreal forests is considered to be limited by the availability of energy, and thus they are expected to display a sensitive and positive response to warming climate (Bonan \& Shugart 1989). However, research from Alaska and northern Europe has also shown that, depending on site and tree species, tree growth may also be limited by water availability (Kärenlampi 1972; Barber et al. 2000; Wilmking et al. 2004; Henttonen et al. 2014). Nevertheless, at larger scales and for different tree species the evidence on environmental determinants of growth variation remains somewhat fragmentary. 
In addition to the environmental limitations of growth, i.e. temperature and water availability, another characteristic feature influencing tree growth in these forests is their tendency to have fairly open canopies. As this allows the trees to avoid competition through crown plasticity (Aakala et al. 2016), it would suggest a minor role of tree-tree competition. However, Fraver et al. (2014) showed that despite the generally sparse nature of canopies, competition seems to play a role as a determinant of tree growth variation. Understanding the role competition plays for different tree species would be important also because the climate response of trees has been shown to be dependent on competition (Bottero et al. 2017). In addition, in naturally-developed forests, the spatial structures and tree size distributions often exhibit a much wider range than managed forests. This means that research findings on tree-tree interactions from orderly-developed managed forests maybe poorly generalizable to structurally complex natural forests.

Past strategies for the statistical modeling of growth of individual trees have varied depending on the variable of interest. Growth as a function of tree size, neighborhood interactions, and/or species has commonly been studied as average growth over multi-year intervals (e.g., (Hartmann et al. 2009; Fraver et al. 2014), whereas high-frequency variation in growth is commonly the focus in dendroclimatological studies, in which case the influence of other variables, such as tree size or age is considered noise (Foster et al. 2016). Moreover, as highlighted by Nehrbass-Ahles et al. (2014), the sampling in those studies is often geared towards specific purposes, such as maximizing the climate signal, and only on selected tree species and hence the results are not easily generalizable and are not representative of tree growth in forested landscapes. However, both categories of data (environmental variables, tree and neighborhood characteristics) are crucial to understand the factors determining the tree growth dynamics (Bowman et al. 2013). 
Here, we assessed the trends and variation in tree growth over the past 50 years in naturally developed, old-growth forests in northern Finland. We employed a randomized network of plots to develop an annual-resolution reconstruction of stand development using tree ring-derived data of tree growth and changing competitive neighborhood. Using these data, and a mixed-effects modeling framework based on the approach presented by Lapointe-Garant et al. (2010) we aimed to 1) quantify variation and trends in tree basal area increment over the past 50 years, and 2) attribute the trends and interannual growth variation to tree- and stand-level variables and environmental drivers, including the influence of competition on the climate response of trees.

\section{Material and methods}

\section{Study areas}

We collected field data in the summer 2012 from Värriö and Maltio strict nature reserves in northeastern Finland (Fig. 1). The reserves are characterized by a mosaic of open mires, forest stands on mineral soils, and treeless areas in the upper slopes of gently rolling mountains (fells). The main tree species in the region are Pinus sylvestris, Picea abies, and Betula pubescens (B. pubescens may in these forests be rarely be mixed with Betula pendula, but we did not separate the two here). Climate in this area is subcontinental, with cold winters and relatively warm summers. Mean annual temperature is $-1^{\circ} \mathrm{C}$. July, the warmest month, has a mean temperature of $13^{\circ} \mathrm{C}$, whereas the coldest month, February, has an average temperature of $-12^{\circ} \mathrm{C}$. Annual precipitation is approx. $660 \mathrm{~mm}$, of which half falls as snow. Soils consist of quaternary deposits and vary from thin soils on stony sites, to deeper soils in the valleys and consist of both sorted soils and moraines.

The reserves, established in 1981 (Värriö) and 1956 (Maltio) have never been logged. The main anthropogenic impact is from reindeer herding. Forest fires have historically been an important 
disturbance in the region, mainly low-intensity surface fires (Aakala 2018). Fire frequencies have

121 decreased considerably in the modern times, and fires are nowadays almost absent in these

122 landscapes. Another major disturbance agent is the B. pubescens defoliator Epirrita autumnata.

123 Damage due to these defoliators is commonly associated with high elevation 'birch zones', but

124 during an outbreak they may also influence B. pubescens and Salix spp. populations in the forested

125 areas at lower elevations. In northeastern Finland, the previous outbreak was in 1965-66 that

126 resulted in considerable B. pubescens mortality (Pulliainen 1976).

Field data

129

130

131

132

133

134

135

136

137

138

139

140

141

142

143

144

We collected field data from 48 randomly located plots in the three study areas Hirvaskangas and Pommituskukkulat in Värriö Strict Nature Reseve and Hongikkovaara in Maltio Strict Nature Reserve, as described in Aakala et al. (2016). In short, a $2 \mathrm{~km} \times 2 \mathrm{~km}$ square was lain on aerial photographs in each study area. This square was then divided into quadrants, and each quadrant was sub-divided into $31.6 \mathrm{~m}$ x $31.6 \mathrm{~m}$ cells ( $0.1 \mathrm{ha})$. We randomly selected four of these 0.1 ha cells within each quadrant as sampling sites (16 per study area, 48 plots total). The first two sites were located close together, after which a buffer of $100 \mathrm{~m}$ was used for all consecutive plots (i.e., a plot was rejected if it the center was located less than $100 \mathrm{~m}$ away from the center of a plot already measured). We considered all 48 plots as old-growth forests, with the ages of the oldest trees in each site ranging from approx. 180 years up to 570 years (Aakala 2018).

Within each plot, we mapped all live and dead trees with diameter at $1.3 \mathrm{~m}$ height (diameter at breast height, DBH) over $10 \mathrm{~cm}$, using the FieldMap measuring system (IFER, Czech Republic) that is designed for mapping forest stands. The system combines an electronic compass and a laser rangefinder to a mapping software. For all trees, we recorded their species, $\mathrm{DBH}$, and height. Following mapping, we took increment core samples from all the trees, using a standard $5.15 \mathrm{~mm}$ 
145 increment borer. We cored live and standing dead trees and cut a wedge from down dead trees,

146 using a chainsaw.

147

148 For an approximation of soil characteristics for water balance modeling we extracted four soil

149 samples from each site, at $2 \mathrm{~m}$ distances from plot center to each cardinal direction. The samples

150 were extracted from the parent material a few $\mathrm{cm}$ below the B horizon. As it was not logistically

151 possible to analyze the influence small-scale (i.e., within-plot) variation, we pooled these four soil

152 samples, and determined an average particle size distribution from the oven-dried $<2 \mathrm{~mm}$ soil

153 fraction using laser diffraction (Coulter LS 230, Beckman Coulter Inc.). Stoniness was similarly

154 determined as a single plot average value, using a metal probe at 16 locations around the plot center

155 (Viro 1952), four points into each cardinal direction, one meter apart. From these data, we

156 calculated the soil moisture at field capacity, using the functions of Saxton et al. (1986).

157

158 Tree ring data and reconstruction of stand structure

159

160 We glued the collected increment cores to core mounts and sanded to fine grit (600 for conifers,

1611000 for deciduous). Owing to fragility of sample wedges from decayed dead trees, we immersed

162 some of the samples in white glue-solution (following Krusic \& Hornbeck 1989, but in normal air

163 pressure), dried, and sanded. Less fragile wedges or sample discs we sanded similar to increment

164 cores. As absent rings can be common in these high-latitude forests (especially during years of poor

165 growth conditions), proper cross-dating is a pre-requisite for any annual resolution analyses using

166 tree ring data as it ensures that each year is assigned its exact year of formation. We cross-dated all

167 samples visually (2102 samples) and measured the tree ring widths using WinDendro software

168 (Regents Instruments Ltd., Canada) for easy samples, and a stereomicroscope with MeasureJ2X 
169

170

171

172

173

174

175

176

177

178

179

180

181

182

183

184

185

186

187

188

189

190

191

192

software connected to a sliding stage (Velmex, Inc., USA) for difficult slow growing conifers and for birch samples.

We based the reconstruction of the development of individual trees on the field data and tree ring data. We back-calculated individual tree sizes by first taking the field-measured tree size as a starting point. We then subtracted bark thickness (using species-specific bark thickness equations; Ilvessalo 1965) and twice the width of the last ring (for diameter), to calculate diameter under bark of the previous year. We then added bark thickness for the new diameter, and added it to this new diameter. This way, we computed tree sizes (over bark) for each tree for each year. If a tree had died during the reconstruction period, it was 'resurrected' at its cross-dated year of death. In years preceding its death it was treated as a live tree and the change of its size was computed accordingly. For downed dead trees the sampling height was sometimes higher than the $1.3 \mathrm{~m}$ height. In this case, we relied on the pipe-model assumption that the area of each ring at the sampling height was equal to the area of the same ring at $1.3 \mathrm{~m}$ height and converted that area to ring width at $1.3 \mathrm{~m}$ height (beginning from the field-measured $\mathrm{DBH}$, minus the bark).

We limited the analysis period to the last 50 years for conifers (1962-2011). From our earlier experience there is a chance that some of the smaller $P$. abies that may have died early during the reconstruction period have already decayed past the point where cross-dating their year of death is possible, but as tree mortality events in these stands were quite rare, these errors should be small.

For B. pubescens, after an initial screening we limited the reconstruction period to the last 30 -years (1982-2011), as the Epirrita-outbreak in 1965-66 resulted in a large number of absent rings in the data set for the trees that survived the outbreak. 
195 For climate data, we used daily meteorological data generated using kriging interpolation of

196 national meteorological data (Venäläinen et al. 2005). The data are interpolated onto a $10 \mathrm{~km} \times 10$

$197 \mathrm{~km}$ grid covering the whole of Finland, and we used the data from the grid point nearest to the

198 Värriö Subarctic Research Station (365 m a.s.1.). We converted the daily data to seasonal (winter=

199 DJF, spring $=$ MAM, summer $=\mathrm{JJA}$, fall $=\mathrm{SON}$ ) temperature and precipitation variables. To 200 correct for temperature differences in elevation, we applied an adiabatic lapse rate of $0.6^{\circ} \mathrm{C} / 100 \mathrm{~m}$.

201 Other predictor variables tested included solar radiation, temperature sum and growing season

202 length. Solar radiation was obtained from Nöjd \& Hari (2001). For calculating the temperature sum 203 we used a $5^{\circ} \mathrm{C}$ threshold value.

In addition to these predictors, we used a daily water balance model, WATBAL (Starr 1999; Starr \& Alam 2015), to reconstruct seasonal soil moisture conditions. WATBAL is based on the model by Bonan (1989), and is a capacity ("bucket") type model that calculates the water balance components and changes in soil moisture available for plants at the end of each day. In addition to climate data, the model takes into account soil characteristics of the site. Hence, the soil moisture deficit values were calculated separately for each site (see Appendix S1 for detailed description).

We tested both current year and previous year variables in the growth modeling. To reduce the number of predictor variables entering the growth model, we used common dendroclimatological

214 methods to screen for candidate climate variables, using correlation between species-specific mean 215 ring-width chronologies and climate variables (see Appendix S2). We entered variables that 216 explained a minimum of $5 \%$ of the variance in the ring-width indices into the model selection 217 procedure (below). For $P$. sylvestris these were: previous spring (MAM) temperature, current spring 
and summer (JJA) mean temperature, previous and current year temperature sum, previous fall

219 (SON) solar radiation, and previous fall precipitation amount. For $P$. abies these were: current

220 summer mean temperature and solar radiation, current year temperature sum, and previous summer

221 precipitation amount. In addition, based on findings from earlier studies (e.g., Mäkinen et al. 2000;

222 Aakala \& Kuuluvainen 2011), we also included current year winter temperatures. For B. pubescens

223 the variables were: previous winter, summer and fall temperature, current summer temperature,

224 previous and current year temperature sum, current year growing season length, and current

225 summer precipitation amount.

WATBAL-modeled soil moisture values were used to calculate drought indices for each site and

year: spring mean soil moisture content (current and previous year), summer mean soil moisture

content (current and previous year), and fall mean soil moisture content (previous year) in the

model selection procedure. We also tested minimum soil moisture values for the same seasons.

Tree-tree competition

233 To quantify the influence of tree-tree competition on tree growth we tested several variants of the

234 neighborhood competition-index (NCI) proposed by (Canham et al. 2004). We modified the index

235 so that all competitor species were treated equally, and the index was of the form:

$237 \quad \sum_{j=1}^{n} \frac{\left(\text { DBH }_{j}\right)^{\alpha}}{\left(\text { distance }_{i j}\right)^{\beta}}$

239 where $D B H_{j}$ is the size of the competitor, and distance $e_{i j}$ is the distance between the focal tree $i$ and 240 the neighboring tree $j$. Constants $\alpha$ and $\beta$ determine the shapes of the effect of the competitor DBH 241 and the distance to the competitor, on NCI. In selecting the exact variant of the competition index 242 for the final modeling, we screened a number of candidate variants for different $\alpha$ and $\beta$, using a 
243 similar procedure as that used by Hartmann et al. (2009). In this, we fit separate models for the

244 exponents $\alpha$ and $\beta(0.5,1,1.5$, and 2.0). In the NCI trees are tallied within a circle of arbitrary size,

245 or 'search radius'. We tested the effect of varying search radii, at $1 \mathrm{~m}$ intervals from $5 \mathrm{~m}$ to $8 \mathrm{~m}$. We

246 judged the performance of different exponents and radii, using Akaike's information criterion

247 (AIC), with substantial differences in model fit indicated by a change in AIC values greater than

248 two. This allowed us to assess which models, and hence predictors, were best supported by the data.

249 Variant with the lowest AIC value was selected.

250

251 In this screening procedure, we used mean basal area increment of the most recent 20-years (1992-

252 2011) as the response variable, and tree size in 1992 and the competition index as predictors. This

253 initial screening for competition indices $(N C I)$ was conducted using mixed effects modeling, with

254 site as a random variable (random intercept). We made the assumption that the competition index

255 that performs best in predicting the 20 -year mean basal area increment is the most suitable also for

256 the interannual analysis of growth. We used weighted edge correction (Getis \& Franklin 1987), and

257 chose $8 \mathrm{~m}$ as the maximum radius (approx. 1/4 of the side of the plot) to avoid unnecessarily large

258 edge effects.

260 The best competition index (judged by the lowest AIC value) for all three species was when $\alpha=0.5$

261 and $\beta=1$ and the search radius was $5 \mathrm{~m}$ for $B$. pubescens, $7 \mathrm{~m}$ for $P$. abies and $8 \mathrm{~m}$ for $P$. sylvestris.

262 It should be noted, however, that there were multiple variants of radius, $\alpha$, and $\beta$ within two $\Delta$ AIC

263 units that is often considered as an indicator of meaningful differences in model performance, so the

264 modeling approach was fairly insensitive to small changes in the parameter values (Appendix S3).

265 In the final model, we calculated the competition index values separately for each year and for each

266 tree, using these fixed values for radius, $\alpha$, and $\beta$. 
269 We modeled the annual variation in basal area increment of all trees that were alive in 2012

270 (although dead trees were included in the reconstruction of the competition index). We built 271 separate models for each of the three species following the protocol of (Zuur et al. 2009). In short,

272 after checking that collinearity of the predictor variables was not an issue, we started out with a full

273 model with the following, annually varying candidate variables: log-transformed tree size,

274 competition index and environmental variables (climate and soil moisture deficit), and static site-

275 level variables soil field capacity, mean organic layer depth and elevation.

276

277

278

279

280

291 We determined the optimal fixed component by fitting (maximum likelihood) the full model, testing 292

We determined the optimal random structure from among the models without random structure, site as random, tree as random, or tree nested within site as random. In all cases the random term was the intercept. As in the competition index selection, we used AIC to select the best model.

Due to the inherent autocorrelation present in tree ring width-derived data, we needed to account for the temporal autocorrelation to satisfy model assumptions of independence of errors. For this, we modeled the autocorrelation between residuals of different time points, using autoregressivemoving average (ARMA) models. We determined the optimal temporal correlation structure of residuals by testing several parameter variants of the ARMA-models. We limited the number of the autoregressive parameters to three and chose the variant based on AIC, and the visual analysis of model residuals as a function of time. Of the tested variants, we selected a third order autoregressive model with no moving average component. Adding more autoregressive parameters led to improvements in the AIC values, but the residuals were clearly positively biased.

\footnotetext{
for the significance of each term using likelihood ratio tests. Each time the least-significant term
} 
was dropped, until all remaining terms were significant. We then fit the final models for each species, using restricted maximum likelihood, and validated the models through visual inspection of residuals (Zuur et al. 2009).

In assessing the model fits it became apparent that the models were unable to predict absent rings that we detected in some of the ring-width series during the cross-dating procedure. Assigning these absent rings unambiguously to specific calendar years was difficult, especially for $B$. pubescens which often has partial (wedging) rings that are possible even if the ring is otherwise wide. Thus trees that had more than $10 \%$ of rings absent during the modelling period were dropped (i.e., more than 5 missing rings for $P$. sylvestris and $P$. abies, and more than 3 missing rings for B. pubescens). Even after dropping these trees from the analyses, the absent rings greatly influenced the goodnessof-fit statistics and we report the results separately with both absent rings both included and omitted.

We also tested whether tree-tree competition influenced how trees respond to the environmental variables that were selected for the final models, by adding the interaction terms between competition and environmental variables. This procedure meant that only the environmental variables that were selected in the final models without interactions were tested. We added the interaction terms to the final models and dropped one interaction term at a time until all were significant. This selection procedure was also done with similar criterion, using likelihood ratio tests.

Models were fitted with original values and with standardized values (zero mean, unit standard deviation) for a rough comparison of the effect sizes of each predictor variable. We report here the standardized parameter estimates (parameter estimates with original values are in Appendix S4). 
318 We assessed the goodness-of-fit for the final models, by computing the amount of variance in the

319 measured basal area increment explained by the model predictions. Finally, to separate the

320 influence of tree- and site-level variables (size, competition) from the environmental variables, we 321 assessed drivers behind these trends by predicting growth, using 1) constant tree size, 2) constant 322 neighborhood competition, and 3) constant tree size and competition (i.e. environmental variables 323 only). All analyses were conducted in R (R Core Team 2016), and packages: dplR (Bunn et al. 324 2016), and nlme (Pinheiro et al. 2016).

\section{Results}

\section{Model goodness-of-fit}

Overall, the model fits varied among species. For P. sylvestris (32 090 tree rings, from 751 trees on 32938 plots), the goodness-of-fit statistic (computed as the percentage of variance in the measured basal area increment explained by the fitted data, with site and tree-level random effect) was $49 \%$

331 (Fig. 2a). For P. abies (23 973 ring width measurements from 582 trees on 34 plots), the goodness332 of-fit statistic value was 68\% (Fig. 2b), and for B. pubescens (6881 ring width measurements from 232 trees on 37 plots), the value was $29 \%$ (Fig. 2c). For all species, model residuals were clearly

334 larger for lower growth rates, i.e. high growth rates were predicted better than low growth rates 335 (Fig. 3a-c).

337 It is noteworthy that these goodness-of-fit values and the spread of the residuals were greatly 338 influenced by absent rings. When we excluded years with absent rings from the calculation of the 339 goodness-of-fit, the value was 70\% (P. sylvestris; 137 absent rings removed), 77\% (P. abies; 28 340 absent rings), and 52\% (B. pubescens, 92 absent rings), and the spread of residuals was more even 341 (Fig. 3a-c). 
344 Of the characteristics of the individual P. sylvestris, tree size was the most important predictor of

345 tree growth with a positive effect (Table 1). Competition (negative effect) and site elevation

346 (positive effect) were also significant predictors. The effect of competition was clearly smaller than

347 the positive influence of tree size or elevation. Of the seasonal environmental variables (climate

348 variables and soil moisture), spring temperatures and temperature sums of the current and previous

349 year were all significant predictors for growth of P. sylvestris, with a positive relationship. In

350 contrast, summer soil moisture deficit of the current and the previous year had a consistent negative

351 relationship with tree growth. Temperature sum had the strongest effect, but overall the influence of

352 environmental variables was weaker than the influence of tree size.

353

354 Similar to $P$. sylvestris, size was the most important predictor of $P$. abies growth, with a positive

355 effect on growth (Table 2). Competition and elevation were also important, and compared to $P$.

356 sylvestris, the effect of competition was clearly stronger. Out of the environmental variables, winter

357 temperatures and drought conditions in the previous summer and especially in the previous fall had

358 a negative effect on growth, whereas summer temperature of the current year had a strong positive

359 influence on growth.

360

361 For B. pubescens (Table 3), tree size and temperature sum had a positive influence on growth,

362 similar to the two conifers. However, in contrast to the two conifers, soil moisture deficits in the

363 spring and summer had a positive influence on B. pubescens growth.

365 Adding interaction terms between competition and environmental variables led to negligible

366 improvements for $P$. sylvestris (AIC $=66732$ vs. 66733 for models without interaction). Of the

367 competition-environment interactions for P. sylvestris, summer soil moisture deficit and 
competition had significant positive interaction, meaning that higher competition decreased the negative influence of summer soil moisture deficit. For $P$. abies, none of the interaction terms were significant.

\section{Growth trends}

On average, tree growth rates clearly increased during the period analyzed, for all three species. This increase was the clearest for P. sylvestris (Fig. 4a) and B. pubescens (Fig 4c), but less evident for P. abies (Fig. 4b). Slope of a linear regression model fitted to the time series of model predictions was $2.09 \mathrm{~mm}^{2} \mathrm{yr}^{-1}$ (CI: 1.95, 2.23) for $P$. sylvestris, $1.21 \mathrm{~mm}^{2} \mathrm{yr}^{-1}(1.02,1.41)$ for $P$. abies, and $2.03 \mathrm{~mm}^{2} \mathrm{yr}^{-1}(1.75,2.31)$ for $B$. pubescens.

To separate the influence of tree and site-level variables from the environmental variables, we fitted models where we held tree size, competition, and both size and competition constant and predicted tree growth (Fig. 4a-c). We then compared the slopes of the fitted models to compare the strength of each predictor as a determinant for growth rate change. For P. sylvestris (Fig. 4a), linear trend in growth rate change over the 50-year interval dropped to $1.30 \mathrm{~mm}^{2} \mathrm{yr}^{-1}$ (CI: 1.17, 1.42) when size was held constant, increased slightly to $2.15 \mathrm{~mm}^{2} \mathrm{yr}^{-1}$ (CI: 2.01, 2.30) when competition was held constant. P. sylvestris model slope was $1.35 \mathrm{~mm}^{2} \mathrm{yr}^{-1}$ when environmental variables alone were included (CI: 1.22, 1.48) when both size and crowding were held constant.

For P. abies (Fig. 4b), the linear trend in growth change over the 50 -year period was $0.19 \mathrm{~mm}^{2} \mathrm{yr}^{-1}$ (CI: $0.02,0.36)$ when size was held constant, $1.28 \mathrm{~mm}^{2} \mathrm{yr}^{-1}$ (CI: $\left.1.08,1.48\right)$ when competition was held constant. When both size and competition were constant (i.e. environmental variables only), the linear trend was $0.25 \mathrm{~mm}^{2} \mathrm{yr}^{-1}$ (CI: 0.08, 0.42). For B. pubescens (Fig. 4c), the linear trend in the 
392 full model was $2.03 \mathrm{~mm}^{2} \mathrm{yr}^{-1}$ (CI: 1.75, 2.31), and when size was held constant $0.95 \mathrm{~mm}^{2} \mathrm{yr}^{-1}$ (CI:

393 0.71, 1.19). Competition was not significant for B. pubescens and hence there was no third model.

394 We note here that in the cases of both constant size and competition, the trend is the result of the 395 environmental variables, as site-level variables (i.e., elevation in the final models for conifers)

396 remain unchanged throughout the period, and random effects consist of intercepts only.

\section{Discussion}

399 We assessed tree growth trends, inter-annual variation and their drivers in three uneven-aged and 400 unmanaged boreal forest landscapes in northern Finland. Unlike most empirical assessments in high 401 latitude forests, our study was carried out using representative sampling of old-growth forests at the 402 landscape level and included all main tree species, which is paramount for accurately depicting 403 growth variations and trends (Nehrbass-Ahles et al. 2014). Based on analyses of national forest 404 inventory data (a systematic sample over the entire country), Kauppi et al. (2014) and Henttonen et 405 al. (2017) similarly found increasing tree growth rates in northern Finland. However, as their

406 analyses included also managed forests, we have here demonstrated for the first time how tree 407 growth has varied in this region in the absence of direct human influence.

In addition to the representative sampling in naturally developed forests, the inter-annual resolution 410 in our analysis has additional benefits for understanding tree growth variation and its drivers. The 411 annual reconstruction allows both an analysis on the changing competitive status (Weber et al. 412 2008), but also of the interactions between stand structure (competitive status of a tree) and climatic 413 variability. This improves our understanding of how different tree species are likely to respond to 414 changing climate and competitive states (Weber et al. 2008; Foster et al. 2016). However, it is 415 worth pointing out that for analyzing tree ring data at an annual resolution, absent rings need to be 416 properly handled through a rigorous cross-dating procedure. 
418 Importantly, summer drought conditions had a small, but consistently negative influence on the 419 growth of both $P$. sylvestris and $P$. abies. The role of droughts or precipitation is in general 420 considered to be minor in these forests (Mikola 1956; Mäkinen et al. 2000), although it has been 421 noted for P. sylvestris on dry sites (Kärenlampi 1972; Henttonen et al. 2014). However, in our analyses the drought limitations applied also to P. abies. As these two species differ in their niches regarding soil properties (Sutinen et al. 2002), our results demonstrated that drought may limit tree growth over a wide range of soil properties. The reason for these effects is likely related to our use of a water balance model parameterized for each study plot, hence leading to a physiologically more realistic representation of soil moisture conditions. This also implies that while the importance of accurate climate information for modeling tree growth is well-recognized (Foster et al. 2016), soil characteristics should also be considered. Taken together, the findings add to the growing body of previously considered problematic (Barber et al. 2000; Wilmking et al. 2004; Clark et al. 2016). For B. pubescens the soil moisture deficit was positive, and hence potentially an additional effect of temperature (cf. Ford et al. 2017).

Besides drought, other environmental variables that influenced tree growth were in line with earlier studies for trees in the northern boreal forests of Europe. Growing season temperature was generally the most important determinant as has been previously shown for all three species in northern Fennoscandian conditions (Henttonen 1990; Helama et al. 2002; Karlsson et al. 2004). Similarly, the negative relationship between $P$. abies growth and winter temperatures has been documented in earlier studies (Mäkinen et al. 2000; Aakala \& Kuuluvainen 2011), and has been explained with the development and maintenance of winter hardiness in warm winters (Bradshaw et al. 2000). 
442 Competition was a fairly modest driver of growth variation, when compared to tree size (effect sizes

443 in Tables 1-2), and it was not significant for B. pubescens. In general, competition is thought to play

444 a greater role as a growth determinant in more productive systems (e.g., Callaway 1998), so the

445 small influence of competition was expected in these high-latitude forests. Although at the stand-

446 level the canopy cover in these old-growth forests is sparse (which would suggest little competition

447 for light) the often-clustered spatial distribution of tree stems (Kreutz et al. 2015), means that

448 competition may still play a role (Fraver et al. 2014). Using the same trees as in the present study,

449 Aakala et al. (2016) showed that competition influenced crown asymmetry so that tree crowns

450 tended to expand away from their competitors, which is a competition-avoidance strategy and

451 probably an important explanation for the minor influence of competition on tree growth. That

452 competition was a stronger determinant for the shade-tolerant $P$. abies was also consistent with the

453 general notion that shade-tolerant tree species are most influenced by competitive interactions

454 (Kunstler et al. 2011). The finding that for B. pubescens competition did not enter the final models

455 is probably also related to the tendency for the species to reproduce from stump and root sprouts, so

456 competition belowground is perhaps not well expressed by a simple competition index.

457

458 A number of studies have demonstrated the interactions between competition and climate variables

459 (Bottero et al. 2017), but the mechanisms are still poorly understood (Grant et al. 2013; Thomas \&

460 Waring 2015). In our analyses, only the summer soil moisture deficit for $P$. sylvestris interacted

461 with competition, and so that stronger tree-tree competition ameliorated the negative effects of

462 summer drought. This somewhat counter-intuitive result might be an expression of soil conditions

463 so that there are more (and/or larger) competitors (and hence higher competition index) on better

464 sites, which would mean that small-scale variation in edaphic conditions may have been an

465 explanation for the findings. All in all, we suspect that these findings are a result of the modest 
influence of competition on growth in these forests in general, precluding the detection of any strong influences from competition on the growth-climate relationships.

When averaged over all trees, we found clearly increasing trends in tree growth in these landscapes. Positive trends were present for all three tree species, and most strikingly so for B. pubescens. In the models, the positive trends were to a large extent attributable to the increasing tree size, which is well-known to be a major determinant for tree growth rates (MacFarlane \& Kobe 2006; Lapointe-

Garant et al. 2010). However, attributing these types of changes in growth trends to specific drivers with statistical modeling is notoriously difficult (Brienen et al. 2017). They are confounded with covarying effects of other trend-like changes in the $20^{\text {th }}$ century, such as the fertilization effects from the globally increasing $\mathrm{CO}_{2}$ concentration, and spring warming, earlier snowmelt and $\mathrm{N}$ deposition that have been shown have occurred in the current study area or in the larger region (Hari et al. 2017; Irannezhad et al. 2017; Palviainen et al. 2017).

However, to examine the role of factors other than increasing tree size (i.e., environmental variables and competition) on these growth trends, we used the models to simulate tree growth with constant size, with constant competition, and with both size and competition held constant. The influence of competition was small, but for $P$. sylvestris and B. pubescens, growth trends were clearly positive even when only environmental variables were considered. For P. abies, growth trends were close to zero when tree size was held constant. Hence, although it was not possible reliably distinguish between different drivers behind the trends, the findings demonstrated clear species dependence in growth trends so that $P$. sylvestris and B. pubescens appeared to have benefited more from the environmental changes during the study period. 
Positive trends in tree growth have been documented earlier in northern Finland, and in managed

491 forests, linked to climate change and forest management (Kauppi et al. 2014; Henttonen et al.

492 2017). However, for naturally developed forests, we speculate that there are two additional factors 493 that may have produced trends at the time scales analyzed here by keeping tree-tree competition

494 low in the past. First, the harsh growth conditions during the so-called Little Ice Age that ended in 495 the early $20^{\text {th }}$ century has likely kept stand density low. The recovery from these conditions has 496 been suggested to have influenced forest structures in northern Sweden (Hofgaard 1993), and 497 increased the tree densities in the nearby treeline ecotone (Aakala et al. 2014). The second change 498 that has occurred is the almost-complete cessation of forest fires in the early $20^{\text {th }}$ century that have 499 influenced particularly the $P$. sylvestris-dominated areas that tended to burn frequently as surface 500 fires (Aakala 2018). This explanation for the positive growth trends would also be consistent with 501 the observations of changing disturbance regimes influencing stand structures and succession 502 (Weber et al. 2008). It is likely that both, cold temperatures and frequent surface fires on drier sites 503 have kept the forests more open and hence tree-tree competition low. Supporting this, our data 504 showed an increase in the mean competition index value, by 15\% from 1962 and 2011, indicating 505 that, on average, the recruitment and increasing neighbor sizes clearly surpassed the effect of tree mortality. Hence, while the role of competition still remained limited, if stand development follows a similar trajectory in the future it seems evident that the role of competition as a determinant of tree 508 growth will increase.

510 An additional explanation for any growth trends could be partial disturbances that relax the 511 competitive pressure on the surviving trees. For B. pubescens, the defoliator outbreak in mid-1960s 512 (Pulliainen 1976) had a large impact in reducing competition for survivors, and this, along with the 513 recovery from the defoliation in general probably explains a major part of the high, positive growth 514 trends for this species. However, except for one plot that had experienced a windthrow during the 
515 study period, field observations suggested that no larger disturbances had occurred in the stands that

516 could have been responsible for creating the observed growth trends, except for the earlier

517 documented cessation of forest fires in the P. sylvestris dominated stands.

518

519 In addition to these variables, the growth of $P$. sylvestris and $P$. abies was influenced by site

520 elevation. Elevation could be expected to influence growth due to its influence on temperature, but

521 the influence here was positive, i.e. trees at higher elevation grew better than trees at lower

522 elevations. It is evident that there was an unmeasured elevation-related covariate influencing growth

523 in our study areas. We nevertheless wanted to keep it in the models, as it would otherwise be

524 included in the site-level random effects for these species.

\section{Conclusions}

527

528

530

531

532

533

534

535

536

537

538

539
Old-growth forests at high latitudes have been considered stable systems, but our analyses showed that tree growth rates have been increasing in the past 50 years (30 years for $B$. pubescens) for all three main species. This growth increase was particularly apparent for P. sylvestris and $B$. pubescens, and may be partly explained by changing climate (end of the Little Ice Age, and $20^{\text {th }}$ century spring warming) observed in this region, but potentially also by long-term changes in the disturbance regimes. Importantly, we found growth to decline during dry summers for both P. abies and $P$. sylvestris, and over a range of soil conditions. As was expected from a low productivity system, competition among trees had a minor influence on tree growth, but showed increases during the time period analyzed.

While tree growth at high latitudes in northern Europe is generally considered to be limited by temperature and hence to benefit from warming climate, the negative effects of drought on $P$. sylvestris and $P$. abies, and the negative effect of warm winters for $P$. abies suggest a complex 
540

541

542

543

544

545

546

response to climate warming in the future. Combined with an increasing trend in the tree-tree competition means that the positive growth trends detected here are unlikely to continue in the future, and the response to warming climate will be species and site-dependent.

\section{Acknowledgements}

We thank Tapio Kara, Timo Kuuluvainen, Yasuhiro Kubota, Toshihide Hirao, Paavo Ojanen and Annukka Valkeapää for field assistance, and Jimi Havisalmi for assistance with the soil samples.

Data accessibility: Growth data and time series of the independent variables are available at DOI: 10.6084/m9.figshare.7151945

\section{Author contributions:}

T.A. conceived of the research idea, collected the data with contributions from M.S., performed statistical analyses with contributions from F.B., and wrote the paper; M.S. computed the soil moisture deficits; all authors discussed the results and commented on the manuscript.

\section{References}

Aakala, T. 2018. Forest fire histories and tree age structures in Värriö and Maltio Strict Nature Reserves, northern Finland. Boreal Environment Research in press.

Aakala, T., Hari, P., Dengel, S., Newberry, S.L., Mizunuma, T. \& Grace, J. 2014. A prominent stepwise advance of the tree line in north-east Finland. Journal of Ecology 102: 1582-1591.

Aakala, T. \& Kuuluvainen, T. 2011. Summer droughts depress radial growth of Picea abies in pristine taiga of the Arkhangelsk province, northwestern Russia. Dendrochronologia 29: 6775.

Aakala, T., Shimatani, K., Abe, T., Kubota, Y.\& Kuuluvainen, T. 2016. Crown asymmetry in high latitude forests: disentangling the directional effects of tree competition and solar radiation. Oikos 125: 1035-1043.

Barber, V.A., Juday, G.P. \& Finney, B.P. 2000. Reduced growth of Alaskan white spruce in the twentieth century from temperature-induced drought stress. Nature 405: 668. 
Bonan, G.B. 1989. A computer model of the solar radiation, soil moisture, and soil thermal regimes in boreal forests. Ecological Modelling 45: 275-306.

Bonan, G.B. \& Shugart, H.H. 1989. Environmental factors and ecological processes in boreal forests. Annual review of ecology and systematics 20: 1-28.

Bottero, A., D'Amato, A.W., Palik, B.J., Bradford, J.B., Fraver, S., Battaglia, M.A. \& Asherin, L.A. 2017. Density-dependent vulnerability of forest ecosystems to drought. Journal of Applied Ecology 54: 1605-1614.

Bowman, D.M., Brienen, R.J., Gloor, E., Phillips, O.L. \& Prior, L.D. 2013. Detecting trends in tree growth: not so simple. Trends in plant science 18: 11-17.

Bradshaw, R.H., Holmqvist, B.H., Cowling, S.A. \& Sykes, M.T. 2000. The effects of climate change on the distribution and management of Picea abies in southern Scandinavia. Canadian Journal of Forest Research 30: 1992-1998.

Brienen, R.J., Gloor, M. \& Ziv, G. 2017. Tree demography dominates long-term growth trends inferred from tree rings. Global Change Biology 23: 474-484.

Bunn, A., Korpela, M., Biondi, F., Campelo, F., Mérian, P., Qeadan, F. \& Zang, C. 2016. dplR: Dendrochronology Program Library in R.

Callaway, R.M. 1998. Competition and facilitation on elevation gradients in subalpine forests of the northern Rocky Mountains, USA. Oikos: 561-573.

Canham, C.D., LePage, P.T. \& Coates, K.D. 2004. A neighborhood analysis of canopy tree competition: effects of shading versus crowding. Canadian Journal of Forest Research 34: 778-787.

Clark, J.S., Iverson, L., Woodall, C.W., Allen, C.D., Bell, D.M., Bragg, D.C., D'amato, A.W., Davis, F.W., Hersh, M.H. \& Ibanez, I. 2016. The impacts of increasing drought on forest dynamics, structure, and biodiversity in the United States. Global Change Biology 22: 23292352.

Coomes, D.A. \& Allen, R.B. 2007. Effects of size, competition and altitude on tree growth. Journal of Ecology 95: 1084-1097.

Ford, K.R., Breckheimer, I.K., Franklin, J.F., Freund, J.A., Kroiss, S.J., Larson, A.J., Theobald, E.J. \& HilleRisLambers, J. 2017. Competition alters tree growth responses to climate at individual and stand scales. Canadian Journal of Forest Research 47: 53-62.

Foster, J.R., Finley, A.O., D'amato, A.W., Bradford, J.B. \& Banerjee, S. 2016. Predicting tree biomass growth in the temperate-boreal ecotone: Is tree size, age, competition, or climate response most important? Global Change Biology 22: 2138-2151.

Fraver, S., D'Amato, A.W., Bradford, J.B., Jonsson, B.G., Jönsson, M. \& Esseen, P.A. 2014. Tree growth and competition in an old-growth Picea abies forest of boreal Sweden: influence of tree spatial patterning. Journal of Vegetation Science 25: 374-385.

Getis, A. \& Franklin, J. 1987. Second-Order Neighborhood Analysis of Mapped Point Patterns. Ecology 68: 473-477.

Gómez-Aparicio, L., García-Valdés, R., Ruíz-Benito, P. \& Zavala, M.A. 2011. Disentangling the relative importance of climate, size and competition on tree growth in Iberian forests: implications for forest management under global change. Global Change Biology 17: 24002414.

Grant, G.E., Tague, C.L. \& Allen, C.D. 2013. Watering the forest for the trees: an emerging priority for managing water in forest landscapes. Frontiers in Ecology and the Environment 11: 314321.

Hari, P., Aakala, T., Hilasvuori, E., Häkkinen, R., Korhola, A., Korpela, M., Linkosalo, T., Mäkinen, H., Nikinmaa, E. \& Nöjd, P. 2017. Reliability of temperature signal in various climate indicators from northern Europe. PloS one 12: e0180042. 
Hartmann, H., Beaudet, M., Mazerolle, M.J. \& Messier, C. 2009. Sugar maple (Acer saccharum Marsh.) growth is influenced by close conspecifics and skid trail proximity following selection harvest. Forest Ecology and Management 258: 823-831.

Helama, S., Lindholm, M., Timonen, M., Meriläinen, J. \& Eronen, M. 2002. The supra-long Scots pine tree-ring record for Finnish Lapland: Part 2, interannual to centennial variability in summer temperatures for 7500 years. The Holocene 12: 681-687.

Henttonen, H.M. 1990. Variation in the diameter growth of Norway spruce in southern Finland [in Finnish with English summary]. University of Helsinki Department of Forest Mensuration and Management Research Notes 25: 1-88.

Henttonen, H.M., Mäkinen, H., Heiskanen, J., Peltoniemi, M., Laurén, A. \& Hordo, M. 2014. Response of radial increment variation of Scots pine to temperature, precipitation and soil water content along a latitudinal gradient across Finland and Estonia. Agricultural and forest meteorology 198: 294-308.

Henttonen, H.M., Nöjd, P. \& Mäkinen, H. 2017. Environment-induced growth changes in the Finnish forests during 1971-2010-An analysis based on National Forest Inventory. Forest Ecology and Management 386: 22-36.

Hofgaard, A. 1993. 50 years of change in a Swedish boreal old-growth Picea abies forest. Journal of Vegetation Science 4: 773-782.

Ilvessalo, Y. 1965. Metsänarvioiminen. WSOY, Porvoo, Finland.

Irannezhad, M., Ronkanen, A.-K., Kiani, S., Chen, D. \& Kløve, B. 2017. Long-term variability and trends in annual snowfall/total precipitation ratio in Finland and the role of atmospheric circulation patterns. Cold Regions Science and Technology 143: 23-31.

Kärenlampi, L. 1972. On the relationships of the Scots pine annual ring width and some climatic variables at the Kevo Subarctic Station. Reports from the Kevo Subarctic Research Station 9: 78-81.

Karlsson, P.S., Tenow, O., Bylund, H., Hoogesteger, J. \& Weih, M. 2004. Determinants of mountain birch growth in situ: effects of temperature and herbivory. Ecography 27: 659667.

Kauppi, P.E., Posch, M. \& Pirinen, P. 2014. Large impacts of climatic warming on growth of boreal forests since 1960. PloS one 9: e111340.

Kreutz, A., Aakala, T., Grenfell, R. \& Kuuluvainen, T. 2015. Spatial tree community structure in three stands across a forest succession gradient in northern boreal Fennoscandia. Silva Fennica 49: 1279.

Krusic Jr, P.J. \& Hornbeck, J.W. 1989. Preserving decayed wood samples for tree-ring measurement. Tree-ring bulletin 49: 23-27.

Kunstler, G., Albert, C.H., Courbaud, B., Lavergne, S., Thuiller, W., Vieilledent, G., Zimmermann, N.E. \& Coomes, D.A. 2011. Effects of competition on tree radial-growth vary in importance but not in intensity along climatic gradients. Journal of Ecology 99: 300-312.

Lapointe-Garant, M.P., Huang, J.G., Gea-Izquierdo, G., Raulier, F., Bernier, P. \& Berninger, F. 2010. Use of tree rings to study the effect of climate change on trembling aspen in Québec. Global Change Biology 16: 2039-2051.

MacFarlane, D.W. \& Kobe, R.K. 2006. Selecting models for capturing tree-size effects on growth resource relationships. Canadian Journal of Forest Research 36: 1695-1704.

Mäkinen, H., Nöjd, P. \& Mielikäinen, K. 2000. Climatic signal in annual growth variation of Norway spruce (Picea abies) along a transect from central Finland to the Arctic timberline. Canadian Journal of Forest Research 30: 769-777.

Mikola, P. 1956. Tree-ring research in Finland. Tree-ring bulletin 21: 16-27.

Nehrbass-Ahles, C., Babst, F., Klesse, S., Nötzli, M., Bouriaud, O., Neukom, R., Dobbertin, M. \& Frank, D. 2014. The influence of sampling design on tree-ring-based quantification of forest growth. Global Change Biology 20: 2867-2885. 
Nöjd, P. \& Hari, P. 2001. Instantaneous PAR estimated using long records of daily temperature and rainfall. Agricultural and forest meteorology 109: 47-59.

Palviainen, M., Pumpanen, J., Berninger, F., Ritala, K., Duan, B., Heinonsalo, J., Sun, H., Köster, E. \& Köster, K. 2017. Nitrogen balance along a northern boreal forest fire chronosequence. PloS one 12: e0174720.

Pinheiro, J., Bates, D., DebRoy, S., Sarkar, D. \& Team, R.C. 2016. nlme: Linear and Nonlinear Mixed Effects Models.

Potapov, P., Hansen, M.C., Laestadius, L., Turubanova, S., Yaroshenko, A., Thies, C., Smith, W., Zhuravleva, I., Komarova, A. \& Minnemeyer, S. 2017. The last frontiers of wilderness: Tracking loss of intact forest landscapes from 2000 to 2013. Science advances 3: e1600821.

Pulliainen, E. 1976. Birch forest damage caused by Oporinia autumnata Bkh. (Lepidoptera, Geometridae) in 1965-66 in eastern Itäkaira, northeastern Lapland. Annales Entomologici Fennici 42: 166-170.

$\mathrm{R}$ Core Team 2016. $R$ : A language and environment for statistical computing. R Foundation for Statistical Computing, Vienna, Austria. URL https://www.R-project.org/.

Saxton, K., Rawls, W.J., Romberger, J. \& Papendick, R. 1986. Estimating generalized soil-water characteristics from texture. Soil Science Society of America Journal 50: 1031-1036.

Starr, M. 1999. WATBAL: A model for estimating monthly water balance components, including soil water fluxes. The Finnish Environment 325: 31-35.

Starr, M. \& Alam, S.A. 2015. Water balance of the Sudanese savannah woodland region. Hydrological Sciences Journal 60: 706-722.

Sutinen, R., Teirilä, A., Pänttäjä, M. \& Sutinen, M.-L. 2002. Distribution and diversity of tree species with respect to soil electrical characteristics in Finnish Lapland. Canadian Journal of Forest Research 32: 1158-1170.

Thomas, Z. \& Waring, K.M. 2015. Enhancing resiliency and restoring ecological attributes in second-growth ponderosa pine stands in northern New Mexico, USA. Forest Science 61: 93104.

Viro, P. 1952. Kivisyyden määrittämisestä. Communicationes Instituti Forestalis Fenniae 40: 8.

Weber, P., Bugmann, H., Fonti, P. \& Rigling, A. 2008. Using a retrospective dynamic competition index to reconstruct forest succession. Forest Ecology and Management 254: 96-106.

Wilmking, M., Juday, G.P., Barber, V.A. \& Zald, H.S. 2004. Recent climate warming forces contrasting growth responses of white spruce at treeline in Alaska through temperature thresholds. Global Change Biology 10: 1724-1736.

Zuur, A., Ieno, E.N., Walker, N., Saveliev, A.A. \& Smith, G.M. 2009. Mixed Effects Models and Extensions in Ecology with R. Springer-Verlag, New York.

\section{Supplementary material}

Appendix S1. Description of the water balance model WATBAL.

Appendix S2. Climate variable screening.

Appendix S3. Competition index selection.

Appendix S4. Non-standardized parameter estimates for the final models. 
712 Table 1. Model summaries for P. sylvestris; $t$ refers to current year variable, $t-1$ to previous year.

713 Separate models were fit with and without interactions (AIC $=66733)$, competition $\times$ environment

$714(\mathrm{AIC}=66732)$. Drought variables were computed, using the WATBAL model. Parameters $\varphi_{1}, \varphi_{2}$,

715 and $\varphi_{3}$ are the parameters of the third-order autoregressive model, used for modeling the temporal

716 autocorrelation of residuals. Random effects (tree within site) are given as standard deviations.

\begin{tabular}{|c|c|c|c|c|c|}
\hline & \multicolumn{5}{|c|}{ Coefficiencts } \\
\hline & Variable & No interaction & & Compet. $\times$ environm. & \\
\hline \multirow{11}{*}{$\begin{array}{l}\text { Fixed } \\
\text { effects }\end{array}$} & Intercept & 5.6032 & $* * *$ & 5.6026 & $* * *$ \\
\hline & $\operatorname{Ln}($ size $)$ & 0.1791 & $* * *$ & 0.1784 & *** \\
\hline & Competition & -0.0718 & $* *$ & -0.0732 & ** \\
\hline & Elevation & 0.2255 & $* *$ & 0.2254 & ** \\
\hline & Spring $T(t-1)$ & 0.0307 & $* * *$ & 0.0307 & *** \\
\hline & Spring $\mathrm{T}(\mathrm{t})$ & 0.0178 & $* * *$ & 0.0179 & *** \\
\hline & Temp. sum (t-1) & 0.0319 & $* * *$ & 0.0315 & *** \\
\hline & Temp. sum $(\mathrm{t})$ & 0.0611 & $* * *$ & 0.0615 & *** \\
\hline & Summer drought $(\mathrm{t}-1)$ & -0.0256 & $* * *$ & -0.0149 & *** \\
\hline & Summer drought (t) & -0.0151 & $* * *$ & -0.0285 & $* * *$ \\
\hline & Competition $\times$ Summer drought $(\mathrm{t}-1)$ & & & 0.0121 & *** \\
\hline \multirow[t]{3}{*}{ ARMA } & $\varphi_{1}$ & 0.3476 & & 0.3479 & \\
\hline & $\varphi_{2}$ & 0.1449 & & 0.1447 & \\
\hline & $\varphi_{3}$ & 0.0940 & & 0.0936 & \\
\hline Random & Site & 0.2408 & & 0.2401 & \\
\hline effects & Tree & 0.5569 & & 0.5572 & \\
\hline (SD) & Residual & 0.7588 & & 0.7586 & \\
\hline
\end{tabular}

718 Significance levels are ${ }^{\mathrm{n} . \mathrm{s} .}-p>0.05,{ }^{*}-p<0.05,{ }^{* *}-\mathrm{p}<0.01,{ }^{* * *}-\mathrm{p}<0.001$.

719 
721 Table 2. Model summaries for $P$. abies; $t$ refers to current year variable, $t$ - 1 to previous year.

722 Interaction terms were not significant and hence only the model without interactions is shown.

723 Notation otherwise similar to Table 1.

\begin{tabular}{|c|c|c|c|}
\hline & Variable & Coefficiencts & \\
\hline Fixed & Intercept & 5.5879 & n.s. \\
\hline \multirow[t]{7}{*}{ effects } & Ln(size) & 0.1757 & $* * *$ \\
\hline & Competition & -0.1200 & $* * *$ \\
\hline & Elevation & 0.1421 & * \\
\hline & Summer $\mathrm{T}(\mathrm{t})$ & 0.1165 & $* * *$ \\
\hline & Winter T (t) & -0.0493 & 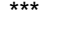 \\
\hline & Fall drought (t-1) & -0.0943 & $* * *$ \\
\hline & Summer drought (t-1) & -0.0115 & ** \\
\hline \multirow[t]{3}{*}{ ARMA } & $\varphi_{1}$ & 0.3702 & \\
\hline & $\varphi_{2}$ & 0.1017 & \\
\hline & $\varphi_{3}$ & 0.1360 & \\
\hline Random & Site & 0.2648 & \\
\hline effects & Tree & 0.5167 & \\
\hline (SD) & Residual & 0.5145 & \\
\hline
\end{tabular}

724 Notes:

725 Significance levels are ${ }^{\text {n.s. }}-p>0.05,{ }^{*}-p<0.05,{ }^{* *}-p<0.01,{ }^{* * *}-p<0.001$.

726 
727 Table 3. Model summaries for $B$. pubescens; $t$ refers to current year variable, $t$-1 to previous year.

728 Interaction terms were not significant and hence only the model without interactions is shown.

729 Notation otherwise similar to Table 1.

\begin{tabular}{|c|c|c|c|}
\hline & Variable & Estimate & \\
\hline \multirow{5}{*}{$\begin{array}{l}\text { Fixed } \\
\text { effects }\end{array}$} & Intercept & 4.9305 & *** \\
\hline & Ln(size) & 0.2383 & $* * *$ \\
\hline & Temp. sum (t) & 0.1061 & *** \\
\hline & Spring drought (t) & 0.0452 & ** \\
\hline & Summer drought (t) & 0.0585 & ** \\
\hline \multirow[t]{3}{*}{ ARMA } & $\varphi_{1}$ & 0.2461 & \\
\hline & $\varphi_{2}$ & -0.0022 & \\
\hline & $\varphi_{3}$ & 0.0861 & \\
\hline Random & Site & 0.1855 & \\
\hline effects & Tree & 0.6150 & \\
\hline (SD) & Residual & 1.2179 & \\
\hline
\end{tabular}

731 Significance levels are ${ }^{\text {n.s. }}-p>0.05,{ }^{*}-p<0.05,{ }^{* *}-p<0.01,{ }^{* * *}-p<0.001$.

732

733 

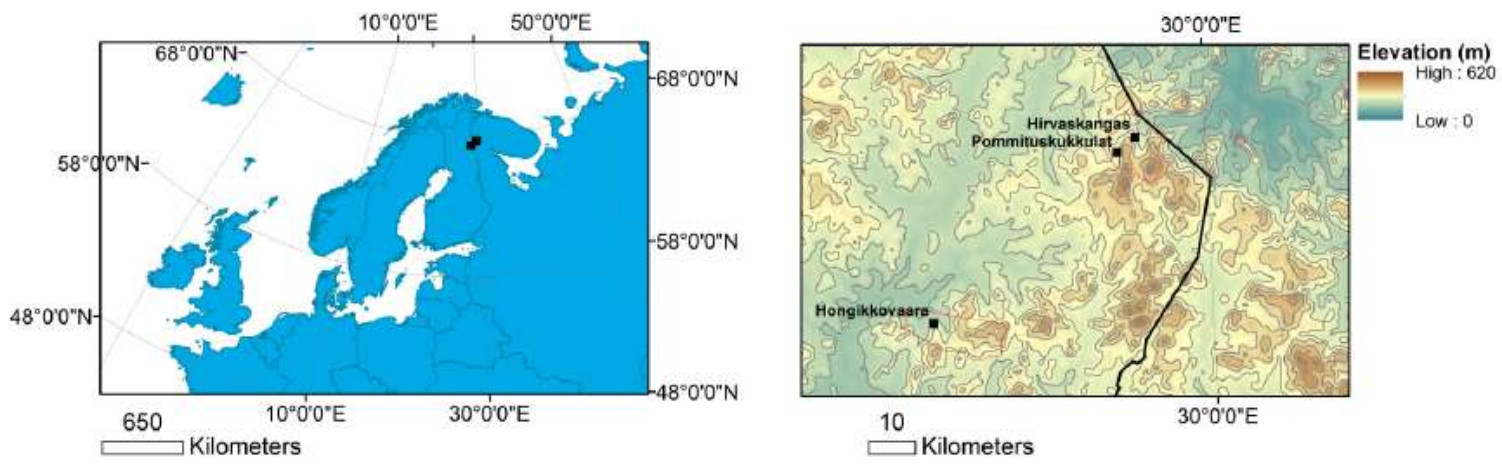

736 Fig. 1. Study landscape locations in the Värriö (Hirvaskangas and Pommituskukkulat) and Maltio

737 (Hongikkovaara) strict nature reserves, northern Finland.

738
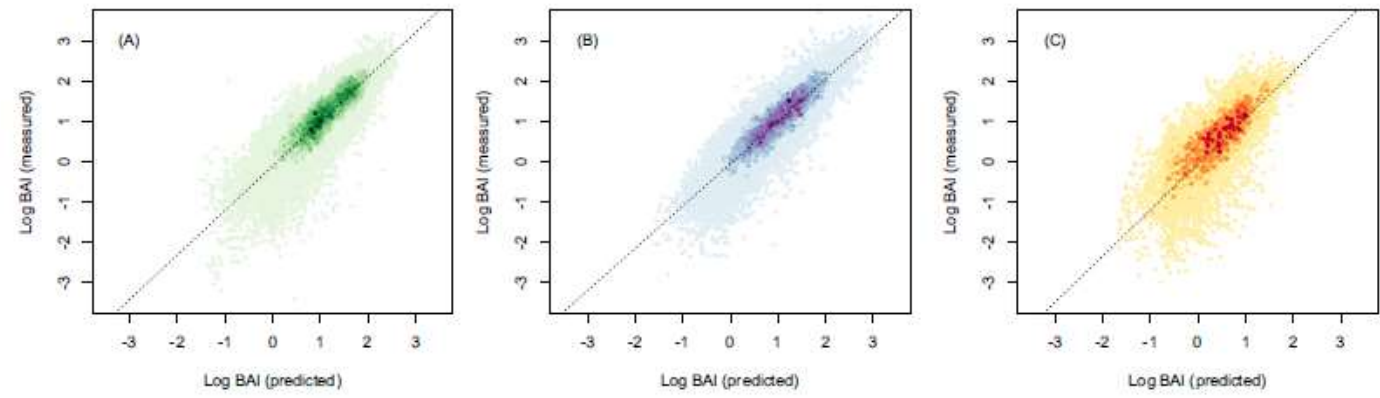

739

740 Fig. 2. Predicted vs. measured basal area increment for P. sylvestris (a), P. abies (b) and B.

741 pubescens (c), without absent rings. Color intensity describes the relative density of points, and the

742 dashed black lines a linear regression line between the fitted and measured basal area increments

\section{3 (BAI).}



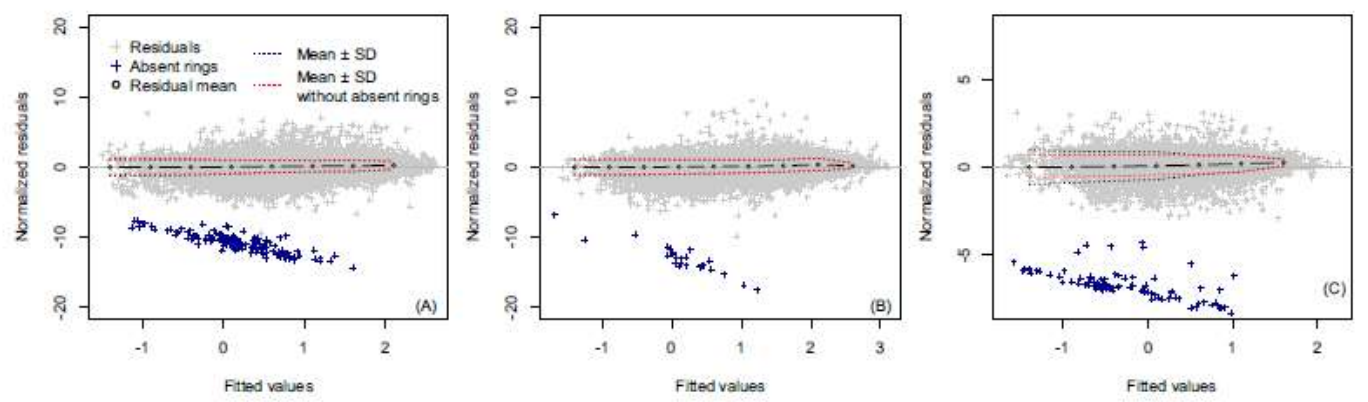

745

746 Fig. 3. The distribution of normalized residuals as a function of predicted values on a logarithmic scale, for P. sylvestris (A), P. abies (B), and B. pubescens (C). Absent rings, and their influence on the distribution of residuals are shown separately. .
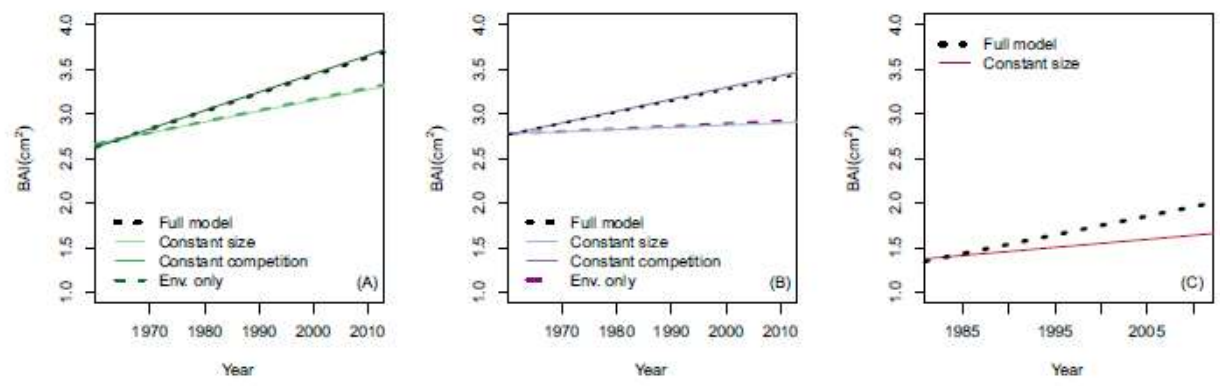

751

752 Fig. 4. Linear regression models over the study period, when simulated using the full model,

753 constant tree size, constant competition and environment variables only, separately for the three

754 species P. sylvestris (a), P. abies (b), and B. pubescens (c). 
Supporting Information to the paper Aakala, T., Berninger, F., and Starr, M. The roles of competition and climate in tree growth variation in northern boreal old-growth forests. Journal of Vegetation Science.

Appendix S1. WATBAL water balance model.

We used a daily water balance model, WATBAL (Starr 1999; Starr \& Alam 2015; Abaker et al. 2017) to reconstruct seasonal soil moisture conditions over the study time period time period. WATBAL is based on the model by Bonan (1989), and is a capacity ("bucket") type model that calculates the water balance output components and changes in storage at the end of each day. The model is of the form

$$
\mathrm{P}=\mathrm{ET}+\mathrm{R}+\mathrm{D}+\Delta \mathrm{SM}+\Delta \mathrm{SOG}
$$

where, $\mathrm{P}=$ precipitation, $\mathrm{ET}=$ evapotranspiration, $\mathrm{R}=$ runoff (surface, shallow subsurface, and preferential flow), $\mathrm{D}=$ Drainage (percolation from the soil layer of interest), $\Delta \mathrm{SM}=$ changes in soil moisture storage of soil layer of interest (typically the rooting zone), and $\Delta \mathrm{SOG}=$ changes in the water equivalent of snow-on-ground (all units are in $\mathrm{mm} \mathrm{day}^{-1}$ ).

Evapotranspiration is calculated from a reference crop evapotranspiration $\left(\mathrm{ET}_{\mathrm{o}}\right)$ value which is subsequently adjusted to a value for the forest stand $\left(\mathrm{ET}_{\mathrm{c}}\right)$ using a crop coefficient approach (Allen et al. 1998) and then for the availability of soil water. $\mathrm{ET}_{\mathrm{o}}$ is calculated using the Jensen-Haise alfalfa reference crop method (Jensen et al. 1990). Runoff in boreal forests can be expected to be restricted to the snowmelt period and in WATBAL is calculated as a fraction of the amount of water available for infiltration, i.e. positive values of rainfall plus snowmelt minus $\mathrm{ET}_{\mathrm{c}}$. The fraction of water available for infiltration depends on the type of soil parent material (till vs. sorted deposits) and its 
texture (Soveri 1985). Snowmelt is calculated using a "temperature-index" method (Dingman 2002) in which the melt coefficient was calculated using the equation developed by Kuusisto (1980), based on the canopy cover fraction and air temperature. Drainage refers to water draining out of the soil layer by gravity, i.e. soil water in excess of field capacity. Soil moisture contents (SM) are calculated using as a piecewise linear function relating the actual to potential evapotranspiration ratio to the relative plant available water content of the soil (Zahner 1967; Dingman 2002). The plant available storage capacity of the soil is defined the difference in the water content of the soil when at field capacity and permanent wilting point. These soil hydraulic properties, as well as the water content of the soil at saturation, were calculated from soil texture data using the pedotransfer functions developed by Saxton and Rawls (2006), and assuming a constant organic matter content of 1\%.

\section{References}

Abaker, W.E., Berninger, F. \& Starr, M. 2017. Changes in soil hydraulic properties, soil moisture and water balance in Acacia senegal plantations of varying age in Sudan. Journal of Arid Environments.

Allen, R.G., Pereira, L.S., Raes, D. \& Smith, M. 1998. Crop evapotranspiration-Guidelines for computing crop water requirements-FAO Irrigation and drainage paper 56. FAO, Rome 300: D05109.

Bonan, G.B. 1989. A computer model of the solar radiation, soil moisture, and soil thermal regimes in boreal forests. Ecological Modelling 45: 275-306.

Dingman, S.L. 2002. Physical Hydrology.2nd Edition ed. Macmillan Publishing Company.

Jensen, M.E., Burman, R.D. \& Allen, R.G. 1990. Evapotranspiration and Irrigation Water Requirements, New York.

Kuusisto, E. 1980. On the values and variability of degree-day melting factor in Finland. Nordic Hydrology 11: 235-242.

Saxton, K.E. \& Rawls, W.J. 2006. Soil water characteristic estimates by texture and organic matter for hydrologic solutions. Soil Science Society of America Journal 70: 1569-1578.

Soveri, J. 1985. Influence of meltwater on the amount and composition of groundwater in quaternary deposits in Finland.

Starr, M. 1999. WATBAL: A model for estimating monthly water balance components, including soil water fluxes. The Finnish Environment 325: 31-35.

Starr, M. \& Alam, S.A. 2015. Water balance of the Sudanese savannah woodland region. Hydrological Sciences Journal 60: 706-722.

Zahner, R. 1967. Refinement in empirical functions for realistic soil-moisture regimes under forest cover. In: Sopper, W.E. \& Lull, H.W. (eds.) Forest Hydrology. Proceedings of a National Science Foundation Advanced Science Seminar, The Pennsylvania State University, Pennsylvania, USA, Aug 29 - Sept 10, 1965., pp. 261-273. Pergamon Press, Oxford. 
Supporting Information to the paper Aakala, T., Berninger, F., and Starr, M. The roles of competition and climate in tree growth variation in northern boreal old-growth forests. Journal of Vegetation Science.

Appendix S2. Screening the climate variables.

Prior to mixed effects modeling, we screened for candidate variables to reduce the number of variables entering the model selection procedure. For this, we first created a mean value chronology for each species, following standard dendroclimatological procedures: we detrended each raw ring-width measurement series with a negative exponential function (Speer 2010), and prewhitened each series before computing a biweight robust mean value for each year. Chronologies were built, using R (R Core Team 2016), package dplR (Bunn et al. 2016).

We then computed correlations between the standardized ring-width indices and seasonal (DJF, MAM, JJA, SON) climate variables, separately for each of the three species (Tables 1, 2, and 3). Variables were tested for the current year, as well as the previous year. Variables, which explained minimum of $5 \%$ of variation in the ring-width chronologies were selected for further analyses. In addition, we included winter temperature for spruce, based on its significance in several earlier studies (Mäkinen et al. 2000; Aakala \& Kuuluvainen 2011). In the screening procedure we used temperature measurements directly (i.e. without correcting for the adiabatic lapse rate) as the ring-width chronologies were constructed from all sites pooled. 
Table 1. Variance in Pinus sylvestris ring width indices explained by seasonal climate variables. Variables that explained a minimum of 5\% in variation in the ring width indices are in boldface.

\begin{tabular}{|c|c|c|c|c|}
\hline Season & Variable & Year & Effect direction & $\mathrm{R}^{2}$ \\
\hline winter & mean temperature & -1 & + & 0.04 \\
\hline spring & mean temperature & -1 & + & 0.19 \\
\hline summer & mean temperature & -1 & + & 0.02 \\
\hline fall & mean temperature & -1 & + & 0.01 \\
\hline winter & precipitation sum & -1 & + & 0.01 \\
\hline spring & precipitation sum & -1 & + & 0.02 \\
\hline summer & precipitation sum & -1 & + & 0 \\
\hline fall & precipitation sum & -1 & - & 0.14 \\
\hline spring & sunshine & -1 & + & 0.02 \\
\hline summer & sunshine & -1 & + & 0 \\
\hline $\begin{array}{c}\text { fall } \\
\text { growing }\end{array}$ & $\begin{array}{l}\text { sunshine } \\
\text { growing season }\end{array}$ & -1 & + & 0.05 \\
\hline $\begin{array}{l}\text { season } \\
\text { growing }\end{array}$ & $\begin{array}{l}\text { length } \\
\text { lentil }\end{array}$ & -1 & + & 0.03 \\
\hline season & temperature sum & -1 & + & 0.09 \\
\hline winter & mean temperature & 0 & + & 0.02 \\
\hline spring & mean temperature & 0 & + & 0.27 \\
\hline summer & mean temperature & 0 & + & 0.1 \\
\hline winter & precipitation sum & 0 & - & 0 \\
\hline spring & precipitation sum & 0 & + & 0.06 \\
\hline summer & precipitation sum & 0 & + & 0 \\
\hline spring & sunshine & 0 & - & 0.03 \\
\hline $\begin{array}{l}\text { summer } \\
\text { growing }\end{array}$ & $\begin{array}{l}\text { sunshine } \\
\text { growing season }\end{array}$ & 0 & + & 0 \\
\hline $\begin{array}{l}\text { season } \\
\text { growing }\end{array}$ & length & 0 & + & 0.02 \\
\hline season & temperature sum & 0 & + & 0.13 \\
\hline
\end{tabular}


Table 2. Variance in Picea abies ring width indices explained by seasonal climate variables.

Variables that explained a minimum of 5\% in variation in the ring width indices are in boldface.

\begin{tabular}{clccc}
\hline season & variable & year & effect & r2 \\
\hline winter & mean temperature & -1 & + & 0 \\
spring & mean temperature & -1 & - & 0 \\
summer & mean temperature & -1 & + & 0.03 \\
fall & mean temperature & -1 & - & 0.01 \\
winter & precipitation sum & -1 & - & 0 \\
spring & precipitation sum & -1 & + & 0 \\
summer & precipitation sum & $-\mathbf{1}$ & - & $\mathbf{0 . 0 7}$ \\
fall & precipitation sum & -1 & - & 0.03 \\
spring & sunshine & -1 & - & 0.01 \\
summer & sunshine & -1 & + & 0.03 \\
fall & sunshine & -1 & + & 0.01 \\
growing season & growing season & & & 0 \\
growing season & length & -1 & - & 0.01 \\
winter & temperature sum & -1 & + & 0.03 \\
spring & mean temperature & 0 & - & 0.03 \\
summer & mean temperature & 0 & - & 0 \\
winter & mean temperature & $\mathbf{0}$ & + & $\mathbf{0 . 4 7}$ \\
spring & precipitation sum & 0 & - & 0.04 \\
summer & precipitation sum & 0 & - & 0 \\
spring & precipitation sum & 0 & + & 0.01 \\
summer & sunshine & 0 & - & 0 \\
growing season & sunshine & $\mathbf{0}$ & $\mathbf{+}$ & $\mathbf{0 . 2}$ \\
growing season & temperature sum & $\mathbf{0}$ & $\mathbf{+}$ & $\mathbf{0 . 3 1}$ \\
\hline & & &
\end{tabular}


Table 3. Variance in Betula pubescens ring width indices explained by seasonal climate variables. Variables that explained a minimum of $5 \%$ in variation in the ring width indices are in boldface.

\begin{tabular}{ccccc}
\hline season & variable & year & effect & r2 \\
\hline winter & mean temperature & $-\mathbf{1}$ & + & $\mathbf{0 . 0 5}$ \\
spring & mean temperature & -1 & - & 0 \\
summer & mean temperature & $-\mathbf{1}$ & $\mathbf{+}$ & $\mathbf{0 . 2 1}$ \\
fall & mean temperature & $-\mathbf{1}$ & $\mathbf{+}$ & $\mathbf{0 . 1 1}$ \\
winter & precipitation sum & -1 & + & 0.01 \\
spring & precipitation sum & -1 & + & 0.01 \\
summer & precipitation sum & -1 & - & 0 \\
fall & precipitation sum & -1 & + & 0 \\
spring & sunshine & -1 & - & 0 \\
summer & sunshine & -1 & - & 0.02 \\
fall & sunshine & -1 & + & 0.03 \\
growing season & growing season & & & \\
growing season & length & -1 & + & 0.04 \\
winter & temperature sum & $\mathbf{- 1}$ & $\mathbf{+}$ & $\mathbf{0 . 1 9}$ \\
spring & mean temperature & 0 & + & 0.01 \\
summer & mean temperature & 0 & + & 0 \\
winter & mean temperature & $\mathbf{0}$ & $\mathbf{+}$ & $\mathbf{0 . 1 8}$ \\
spring & precipitation sum & 0 & - & 0 \\
summer & precipitation sum & 0 & + & 0.02 \\
spring & precipitation sum & $\mathbf{0}$ & $\mathbf{+}$ & $\mathbf{0 . 0 6}$ \\
summer & sunshine & 0 & + & 0.03 \\
autumn & sunshine & 0 & - & 0 \\
& sunshine & 0 & - & 0.03 \\
growing season & growing season & $\mathbf{0}$ & $\mathbf{+}$ & $\mathbf{0 . 1 4}$ \\
growing season & temperature sum & $\mathbf{0}$ & $\mathbf{+}$ & $\mathbf{0 . 2 6}$ \\
\hline & & &
\end{tabular}

\section{References}

Aakala, T. \& Kuuluvainen, T. 2011. Summer droughts depress radial growth of Picea abies in pristine taiga of the Arkhangelsk province, northwestern Russia. Dendrochronologia 29: 67-75. 
Bunn, A., Korpela, M., Biondi, F., Campelo, F., Mérian, P., Qeadan, F. \& Zang, C. 2016. dplR: Dendrochronology Program Library in $R$.

Mäkinen, H., Nöjd, P. \& Mielikäinen, K. 2000. Climatic signal in annual growth variation of Norway spruce (Picea abies) along a transect from central Finland to the Arctic timberline. Canadian Journal of Forest Research 30: 769-777.

$\mathrm{R}$ Core Team 2016. $R$ : A language and environment for statistical computing. $\mathrm{R}$ Foundation for Statistical Computing, Vienna, Austria. URL https://www.R-project.org/.

Speer, J.H. 2010. Fundamentals of tree-ring research. University of Arizona Press. 
Supporting Information to the paper Aakala, T., Berninger, F., and Starr, M. The roles of competition and climate in tree growth variation in northern boreal old-growth forests. Journal of Vegetation Science.

Appendix S3. Screening for the competition index.

To quantify the influence of tree-tree competition on tree growth, we used the neighborhood competition-index proposed by Canham et al. (2004). The index requires that constants $\alpha$ and $\beta$, as well as a search radius for competing trees are carefully selected. Following the approach taken by Hartmann et al. (2009), we tested several variants for each of these constants: $\alpha$ and $\beta$ were given values $0.5,1,1.5$, and 2.0 , and the search radius values were tested at $1 \mathrm{~m}$ intervals from $5 \mathrm{~m}$ to $8 \mathrm{~m}$.

In this screening procedure, we used 20-year mean basal-area increment as the response variable, and tree size and the competition index as the predictors. This initial screening for competition indices was conducted using mixed effects modeling, with site as a random variable, and was of the form:

$\ln \left(B A I_{20}\right)=\ln (D B H)+\ln (N C I)+$ site $+\varepsilon$ 
We made the assumption that the relationship between tree growth and competition is static, i.e., the competition index that performs best in predicting the 20 -year mean basal area increment is also the most suitable also for the interannual analysis of growth. We used weighted edge correction (Getis \& Franklin 1987), and chose $8 \mathrm{~m}$ as the maximum radius (approx. 1/4 of the side of the plot) to avoid unnecessarily large edge effects. The indices with different variants $\alpha, \beta$ and radius were ranked, using the Akaike Information Criteria (AIC), separately for P. sylvestris (Table 1), P. abies (Table 2), and B. pubescencs (Table 3).

Table 1. Competition indices ranked for P. sylvestris.

\begin{tabular}{cccccc}
\hline Rank & Radius & $\alpha$ & $\beta$ & AIC & $\Delta$ AIC \\
\hline 1 & 8 & 0.5 & 1 & 1741.742 & 0 \\
2 & 7 & 0.5 & 0.5 & 1741.934 & 0.192 \\
3 & 7 & 0.5 & 1 & 1741.993 & 0.251 \\
4 & 6 & 0.5 & 0.5 & 1742.178 & 0.436 \\
5 & 8 & 0.5 & 0.5 & 1742.254 & 0.512 \\
6 & 8 & 1 & 1.5 & 1742.258 & 0.516 \\
7 & 8 & 0.5 & 1.5 & 1742.259 & 0.517 \\
8 & 7 & 1 & 1 & 1742.455 & 0.713 \\
9 & 6 & 0.5 & 1 & 1742.477 & 0.735 \\
10 & 8 & 1 & 2 & 1742.505 & 0.763 \\
11 & 7 & 1 & 1.5 & 1742.519 & 0.777 \\
12 & 7 & 0.5 & 1.5 & 1742.622 & 0.88 \\
13 & 8 & 1 & 1 & 1742.646 & 0.904 \\
14 & 7 & 1 & 0.5 & 1742.73 & 0.988 \\
15 & 7 & 1 & 2 & 1742.931 & 1.189 \\
16 & 8 & 1.5 & 2 & 1742.934 & 1.192 \\
17 & 6 & 0.5 & 1.5 & 1743.043 & 1.301 \\
18 & 7 & 1.5 & 1.5 & 1743.058 & 1.316 \\
19 & 6 & 1 & 0.5 & 1743.093 & 1.351 \\
20 & 7 & 1.5 & 2 & 1743.099 & 1.357 \\
21 & 6 & 1 & 1 & 1743.121 & 1.379 \\
22 & 7 & 1.5 & 1 & 1743.207 & 1.465 \\
23 & 8 & 1.5 & 1.5 & 1743.207 & 1.465 \\
& 7 & & & &
\end{tabular}




\begin{tabular}{|c|c|c|c|c|c|}
\hline 24 & 8 & 0.5 & 2 & 1743.215 & 1.473 \\
\hline 25 & 6 & 1 & 1.5 & 1743.3 & 1.558 \\
\hline 26 & 7 & 0.5 & 2 & 1743.422 & 1.68 \\
\hline 27 & 8 & 1 & 0.5 & 1743.503 & 1.761 \\
\hline 28 & 7 & 1.5 & 0.5 & 1743.518 & 1.776 \\
\hline 29 & 7 & 2 & 2 & 1743.563 & 1.821 \\
\hline 30 & 6 & 1 & 2 & 1743.641 & 1.899 \\
\hline 31 & 6 & 0.5 & 2 & 1743.658 & 1.916 \\
\hline 32 & 7 & 2 & 1.5 & 1743.658 & 1.916 \\
\hline 33 & 8 & 2 & 2 & 1743.712 & 1.97 \\
\hline 34 & 8 & 1.5 & 1 & 1743.795 & 2.053 \\
\hline 35 & 6 & 1.5 & 1 & 1743.854 & 2.112 \\
\hline 36 & 7 & 2 & 1 & 1743.855 & 2.113 \\
\hline 37 & 6 & 1.5 & 1.5 & 1743.875 & 2.133 \\
\hline 38 & 6 & 1.5 & 0.5 & 1743.886 & 2.144 \\
\hline 39 & 6 & 1.5 & 2 & 1743.959 & 2.217 \\
\hline 40 & 8 & 2 & 1.5 & 1744.123 & 2.381 \\
\hline 41 & 7 & 2 & 0.5 & 1744.146 & 2.404 \\
\hline 42 & 5 & 0.5 & 2 & 1744.258 & 2.516 \\
\hline 43 & 5 & 0.5 & 1.5 & 1744.265 & 2.523 \\
\hline 44 & 6 & 2 & 1.5 & 1744.439 & 2.697 \\
\hline 45 & 6 & 2 & 2 & 1744.44 & 2.698 \\
\hline 46 & 6 & 2 & 1 & 1744.455 & 2.713 \\
\hline 47 & 5 & 0.5 & 1 & 1744.464 & 2.722 \\
\hline 48 & 6 & 2 & 0.5 & 1744.494 & 2.752 \\
\hline 49 & 8 & 1.5 & 0.5 & 1744.544 & 2.802 \\
\hline 50 & 8 & 2 & 1 & 1744.686 & 2.944 \\
\hline 51 & 5 & 0.5 & 0.5 & 1744.787 & 3.045 \\
\hline 52 & 8 & 2 & 0.5 & 1745.314 & 3.572 \\
\hline 53 & 5 & 1 & 2 & 1745.489 & 3.747 \\
\hline 54 & 5 & 1 & 1.5 & 1745.72 & 3.978 \\
\hline 55 & 5 & 1 & 1 & 1745.973 & 4.231 \\
\hline 56 & 5 & 1 & 0.5 & 1746.218 & 4.476 \\
\hline 57 & 5 & 1.5 & 2 & 1746.551 & 4.809 \\
\hline 58 & 5 & 1.5 & 1.5 & 1746.752 & 5.01 \\
\hline 59 & 5 & 1.5 & 1 & 1746.941 & 5.199 \\
\hline 60 & 5 & 1.5 & 0.5 & 1747.109 & 5.367 \\
\hline 61 & 5 & 2 & 2 & 1747.309 & 5.567 \\
\hline 62 & 5 & 2 & 1.5 & 1747.466 & 5.724 \\
\hline 63 & 5 & 2 & 1 & 1747.607 & 5.865 \\
\hline 64 & 5 & 2 & 0.5 & 1747.732 & 5.99 \\
\hline
\end{tabular}

Table 2. Competition indices ranked for $P$. abies. 


\begin{tabular}{|c|c|c|c|c|c|}
\hline Rank & Radius & $\alpha$ & $\beta$ & AIC & $\triangle \mathrm{AIC}$ \\
\hline 1 & 7 & 0.5 & 1 & 1090.07 & 0 \\
\hline 2 & 7 & 0.5 & 0.5 & 1090.37 & 0.3 \\
\hline 3 & 7 & 0.5 & 1.5 & 1091.319 & 1.249 \\
\hline 4 & 8 & 0.5 & 1 & 1092.442 & 2.372 \\
\hline 5 & 8 & 0.5 & 1.5 & 1092.735 & 2.665 \\
\hline 6 & 7 & 0.5 & 2 & 1093.228 & 3.158 \\
\hline 7 & 8 & 0.5 & 0.5 & 1093.719 & 3.649 \\
\hline 8 & 6 & 0.5 & 1.5 & 1093.901 & 3.831 \\
\hline 9 & 8 & 0.5 & 2 & 1093.911 & 3.841 \\
\hline 10 & 6 & 0.5 & 1 & 1093.913 & 3.843 \\
\hline 11 & 7 & 1 & 1.5 & 1094.237 & 4.167 \\
\hline 12 & 6 & 0.5 & 2 & 1094.595 & 4.525 \\
\hline 13 & 7 & 1 & 2 & 1094.63 & 4.56 \\
\hline 14 & 6 & 0.5 & 0.5 & 1094.702 & 4.632 \\
\hline 15 & 7 & 1 & 1 & 1094.73 & 4.66 \\
\hline 16 & 7 & 1 & 0.5 & 1095.651 & 5.581 \\
\hline 17 & 8 & 1 & 2 & 1096.182 & 6.112 \\
\hline 18 & 8 & 1 & 1.5 & 1096.269 & 6.199 \\
\hline 19 & 5 & 0.5 & 2 & 1096.371 & 6.301 \\
\hline 20 & 7 & 1.5 & 2 & 1096.475 & 6.405 \\
\hline 21 & 5 & 0.5 & 1.5 & 1096.774 & 6.704 \\
\hline 22 & 7 & 1.5 & 1.5 & 1096.972 & 6.902 \\
\hline 23 & 6 & 1 & 2 & 1097.018 & 6.948 \\
\hline 24 & 8 & 1 & 1 & 1097.231 & 7.161 \\
\hline 25 & 6 & 1 & 1.5 & 1097.312 & 7.242 \\
\hline 26 & 5 & 0.5 & 1 & 1097.656 & 7.586 \\
\hline 27 & 7 & 1.5 & 1 & 1097.764 & 7.694 \\
\hline 28 & 6 & 1 & 1 & 1097.983 & 7.913 \\
\hline 29 & 7 & 2 & 2 & 1098.266 & 8.196 \\
\hline 30 & 8 & 1.5 & 2 & 1098.382 & 8.312 \\
\hline 31 & 7 & 1.5 & 0.5 & 1098.494 & 8.424 \\
\hline 32 & 8 & 1 & 0.5 & 1098.53 & 8.46 \\
\hline 33 & 6 & 1 & 0.5 & 1098.706 & 8.636 \\
\hline 34 & 5 & 0.5 & 0.5 & 1098.731 & 8.661 \\
\hline 35 & 7 & 2 & 1.5 & 1098.919 & 8.849 \\
\hline 36 & 6 & 1.5 & 2 & 1098.954 & 8.884 \\
\hline 37 & 8 & 1.5 & 1.5 & 1099.18 & 9.11 \\
\hline 38 & 5 & 1 & 2 & 1099.41 & 9.34 \\
\hline 39 & 6 & 1.5 & 1.5 & 1099.546 & 9.476 \\
\hline 40 & 7 & 2 & 1 & 1099.604 & 9.534 \\
\hline 41 & 5 & 1 & 1.5 & 1100.059 & 9.989 \\
\hline 42 & 7 & 2 & 0.5 & 1100.14 & 10.07 \\
\hline
\end{tabular}




\begin{tabular}{cccccc}
43 & 6 & 1.5 & 1 & 1100.188 & 10.118 \\
44 & 8 & 1.5 & 1 & 1100.218 & 10.148 \\
45 & 8 & 2 & 2 & 1100.33 & 10.26 \\
46 & 6 & 2 & 2 & 1100.437 & 10.367 \\
47 & 6 & 1.5 & 0.5 & 1100.712 & 10.642 \\
48 & 5 & 1 & 1 & 1100.793 & 10.723 \\
49 & 6 & 2 & 1.5 & 1101.004 & 10.934 \\
50 & 8 & 1.5 & 0.5 & 1101.088 & 11.018 \\
51 & 8 & 2 & 1.5 & 1101.177 & 11.107 \\
52 & 5 & 1.5 & 2 & 1101.299 & 11.229 \\
53 & 5 & 1 & 0.5 & 1101.43 & 11.36 \\
54 & 6 & 2 & 1 & 1101.522 & 11.452 \\
55 & 5 & 1.5 & 1.5 & 1101.873 & 11.803 \\
56 & 6 & 2 & 0.5 & 1101.909 & 11.839 \\
57 & 8 & 2 & 1 & 1101.976 & 11.906 \\
58 & 5 & 1.5 & 1 & 1102.405 & 12.335 \\
59 & 8 & 2 & 0.5 & 1102.546 & 12.476 \\
60 & 5 & 2 & 2 & 1102.561 & 12.491 \\
61 & 5 & 1.5 & 0.5 & 1102.821 & 12.751 \\
62 & 5 & 2 & 1.5 & 1103.016 & 12.946 \\
63 & 5 & 2 & 1 & 1103.409 & 13.339 \\
64 & 5 & 2 & 0.5 & 1103.705 & 13.635 \\
\hline & & & & &
\end{tabular}

Table 3. Competition indices ranked for Betula pubescens.

\begin{tabular}{cccccc}
\hline Rank & radius & $\alpha$ & $\beta$ & AIC & $\Delta$ AIC \\
\hline 1 & 5 & 0.5 & 1 & 481.645 & 0 \\
2 & 5 & 0.5 & 0.5 & 482.531 & 0.886 \\
3 & 6 & 0.5 & 1 & 482.916 & 1.271 \\
4 & 5 & 0.5 & 1.5 & 483.246 & 1.601 \\
5 & 8 & 0.5 & 1 & 484.003 & 2.358 \\
6 & 6 & 0.5 & 1.5 & 484.062 & 2.417 \\
7 & 8 & 0.5 & 1.5 & 484.589 & 2.944 \\
8 & 6 & 0.5 & 0.5 & 484.608 & 2.963 \\
9 & 7 & 0.5 & 1 & 485.077 & 3.432 \\
10 & 5 & 1 & 1.5 & 485.112 & 3.467 \\
11 & 6 & 1 & 1.5 & 485.174 & 3.529 \\
12 & 7 & 0.5 & 1.5 & 485.177 & 3.532 \\
13 & 5 & 1 & 2 & 485.56 & 3.915 \\
14 & 6 & 1 & 2 & 485.577 & 3.932 \\
15 & 5 & 1 & 1 & 485.586 & 3.941 \\
16 & 6 & 1 & 1 & 486.1 & 4.455 \\
17 & 5 & 0.5 & 2 & 486.236 & 4.591
\end{tabular}




$\begin{array}{lccccc}18 & 8 & 0.5 & 0.5 & 486.706 & 5.061 \\ 19 & 5 & 1 & 0.5 & 486.759 & 5.114 \\ 20 & 6 & 0.5 & 2 & 486.771 & 5.126 \\ 21 & 8 & 1 & 2 & 486.852 & 5.207 \\ 22 & 8 & 1 & 1.5 & 486.901 & 5.256 \\ 23 & 6 & 1.5 & 2 & 486.958 & 5.313 \\ 24 & 8 & 0.5 & 2 & 487.053 & 5.408 \\ 25 & 7 & 0.5 & 2 & 487.237 & 5.592 \\ 26 & 5 & 1.5 & 2 & 487.304 & 5.659 \\ 27 & 6 & 1.5 & 1.5 & 487.529 & 5.884 \\ 28 & 7 & 1 & 2 & 487.535 & 5.89 \\ 29 & 5 & 1.5 & 1.5 & 487.583 & 5.938 \\ 30 & 7 & 0.5 & 0.5 & 487.767 & 6.122 \\ 31 & 7 & 1 & 1.5 & 487.942 & 6.297 \\ 32 & 6 & 1 & 0.5 & 487.97 & 6.325 \\ 33 & 5 & 1.5 & 1 & 488.235 & 6.59 \\ 34 & 8 & 1 & 1 & 488.528 & 6.883 \\ 35 & 6 & 2 & 2 & 488.605 & 6.96 \\ 36 & 6 & 1.5 & 1 & 488.718 & 7.073 \\ 37 & 5 & 2 & 2 & 488.894 & 7.249 \\ 38 & 8 & 1.5 & 2 & 488.947 & 7.302 \\ 39 & 5 & 1.5 & 0.5 & 489.102 & 7.457 \\ 40 & 5 & 2 & 1.5 & 489.299 & 7.654 \\ 41 & 6 & 2 & 1.5 & 489.397 & 7.752 \\ 42 & 7 & 1 & 1 & 489.612 & 7.967 \\ 43 & 5 & 2 & 1 & 489.881 & 8.236 \\ 44 & 7 & 1.5 & 2 & 489.944 & 8.299 \\ 45 & 8 & 1.5 & 1.5 & 489.997 & 8.352 \\ 46 & 6 & 1.5 & 0.5 & 490.162 & 8.517 \\ 47 & 6 & 2 & 1 & 490.489 & 8.844 \\ 48 & 5 & 2 & 0.5 & 490.537 & 8.892 \\ 49 & 8 & 1 & 0.5 & 490.98 & 9.335 \\ 50 & 7 & 1.5 & 1.5 & 491.048 & 9.403 \\ 51 & 8 & 2 & 2 & 491.07 & 9.425 \\ 52 & 6 & 2 & 0.5 & 491.618 & 9.973 \\ 53 & 8 & 1.5 & 1 & 491.716 & 10.071 \\ 54 & 7 & 1 & 0.5 & 491.839 & 10.194 \\ 55 & 7 & 2 & 2 & 492.071 & 10.426 \\ 56 & 8 & 2 & 1.5 & 492.281 & 10.636 \\ 57 & 7 & 1.5 & 1 & 492.597 & 10.952 \\ 58 & 7 & 2 & 1.5 & 493.177 & 11.532 \\ 59 & 8 & 1.5 & 0.5 & 493.413 & 11.768 \\ 60 & 8 & 2 & 1 & 493.702 & 12.057\end{array}$




\begin{tabular}{cccccc}
61 & 7 & 1.5 & 0.5 & 494.1 & 12.455 \\
62 & 7 & 2 & 1 & 494.414 & 12.769 \\
63 & 8 & 2 & 0.5 & 494.892 & 13.247 \\
64 & 7 & 2 & 0.5 & 495.479 & 13.834 \\
\hline
\end{tabular}

\section{References}

Canham, C.D., LePage, P.T. \& Coates, K.D. 2004. A neighborhood analysis of canopy tree competition: effects of shading versus crowding. Canadian Journal of Forest Research 34: 778-787.

Getis, A. \& Franklin, J. 1987. Second-Order Neighborhood Analysis of Mapped Point Patterns. Ecology 68: 473-477.

Hartmann, H., Beaudet, M., Mazerolle, M.J. \& Messier, C. 2009. Sugar maple (Acer saccharum Marsh.) growth is influenced by close conspecifics and skid trail proximity following selection harvest. Forest Ecology and Management 258: 823-831. 
Supporting Information to the paper Aakala, T., Berninger, F., and Starr, M. The roles of competition and climate in tree growth variation in northern boreal old-growth forests. Journal of Vegetation Science.

Appendix S4. Model summaries for models without standardization.

Table 1. Model summaries for Pinus sylvestris; $t$ refers to current year variable, $t-1$ to previous year.

\begin{tabular}{|c|c|c|c|c|c|}
\hline & & No interaction & & Compet. $\times$ environm. & \\
\hline & Variable & Estimate & & Estimate & \\
\hline Fixed & Intercept & -0.0118 & n.s. & -0.2594 & $* \star \star *$ \\
\hline \multirow[t]{10}{*}{ effects } & $\operatorname{Ln}(\operatorname{size})$ & 0.4573 & *** & 0.4654 & $\star \star \star \star \star * ⿻$ \\
\hline & Competition & -0.0002 & ${ }_{\star \star \star}^{* \star}$ & 0.0004 & n.s. \\
\hline & Elevation & 0.0069 & & 0.0069 & \\
\hline & Spring $T(t-1)$ & 0.0231 & *** & 0.0230 & *** \\
\hline & Spring $T(t)$ & 0.0130 & & 0.0130 & \\
\hline & Temp. sum (t-1) & 0.2630 & 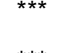 & 0.2591 & 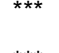 \\
\hline & Temp. sum (t) & 0.4903 & $\star \star \star \star x$ & 0.4927 & \\
\hline & Summer drought (t-1) & -0.0043 & *** & -0.0025 & 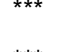 \\
\hline & Summer drought (t) & -0.0025 & $x^{\star \star \star}$ & -0.0074 & 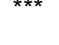 \\
\hline & Competition $\times$ Summer drought $(\mathrm{t}-1)$ & & & 0.0000 & \\
\hline \multirow[t]{3}{*}{ ARMA } & $\varphi_{1}$ & 0.3477 & & 0.3479 & \\
\hline & $\varphi_{2}$ & 0.1450 & & 0.1449 & \\
\hline & $\varphi_{3}$ & 0.0941 & & 0.0937 & \\
\hline Random & Site & 0.2440 & & 0.2436 & \\
\hline effects & Tree & 0.5560 & & 0.5563 & \\
\hline (SD) & Residual & 0.7590 & & 0.7589 & \\
\hline
\end{tabular}

Notes:

Significance levels are ${ }^{\text {n.s. }}-p>0.05,{ }^{*}-p<0.05,{ }^{* *}-p<0.01,{ }^{, * *}-p<0.001$. Temperature sum is re-scaled (divided by 1000) for a more informative parameter value 
Table 2. Model summaries for Picea abies; $t$ refers to current year variable, $t$-1 to previous year.

\begin{tabular}{|c|c|c|c|}
\hline & Variable & Estimate & \\
\hline \multirow{8}{*}{$\begin{array}{l}\text { Fixed } \\
\text { effects }\end{array}$} & Intercept & -0.0390 & \multirow{2}{*}{$\begin{array}{l}\text { n.s. } \\
* * *\end{array}$} \\
\hline & $\operatorname{Ln}($ size $)$ & 0.4747 & \\
\hline & Competition & -0.0004 & \multirow{6}{*}{$\begin{array}{l}\star \star \star \\
\star \\
\star \star \\
\star \star \star \\
\star \star \star \\
\star \star \star \star \\
\star \star\end{array}$} \\
\hline & Elevation & 0.0056 & \\
\hline & Summer $\mathrm{T}(\mathrm{t})$ & 0.0983 & \\
\hline & Winter $\mathrm{T}(\mathrm{t})$ & -0.0224 & \\
\hline & Fall drought (t-1) & -0.0051 & \\
\hline & Summer drought (t-1) & -0.0007 & \\
\hline \multirow[t]{3}{*}{ ARMA } & $\varphi_{1}$ & 0.3702 & \\
\hline & $\varphi_{2}$ & 0.1017 & \\
\hline & $\varphi_{3}$ & 0.1360 & \\
\hline Random & Site & 0.2648 & \\
\hline effects & Tree & 0.5167 & \\
\hline (SD) & Residual & 0.5145 & \\
\hline
\end{tabular}

Significance levels are ${ }^{\text {n.s. }}-p>0.05,{ }^{*}-p<0.05,{ }^{\star \star}-p<0.01,{ }^{* \star *}-p<0.001$. Temperature sum is re-scaled (divided by 1000$)$ for a more informative parameter value

Table 3. Model summaries for Betula pubescens; $t$ refers to current year variable, $t-1$ to previous year.

\begin{tabular}{llrl}
\hline & Variable & Estimate & \\
\hline Fixed & Intercept & 1.1281 & n.s. \\
effects & Ln(size) & 0.7250 & ${ }^{* \star *}$ \\
& Temp. sum (t) & 0.0093 & ${ }^{* *}$ \\
& Spring drought (t) & 0.0018 & ${ }^{* *}$ \\
& Summer drought (t) & 0.0477 & \\
\cline { 2 - 2 } & $\varphi_{1}$ & 0.2460 & \\
& $\varphi_{2}$ & -0.0022 & \\
& $\varphi_{3}$ & 0.0861 & \\
Random & Site & 0.1855 & \\
effects & Tree & 0.6150 & \\
(SD) & Residual & 1.2179 & \\
Notes: & & &
\end{tabular}


Significance levels are ${ }^{\text {n.s. }}-p>0.05,{ }^{*}-p<0.05,{ }^{* \star}-p<0.01,{ }^{* \star *}-p<0.001$. Temperature sum is re-scaled (divided by 1000) for a more informative parameter value 